\title{
SNOW-FENCE EXPERIMENTS IN ALPINE AREAS
}

\author{
By M. Martinelli, Jr \\ (Rocky Mountain Forest and Range Experiment Station," Forest Service, U.S. Department \\ of Agriculture, Fort Collins, Colorado $805_{2}$ I, U.S.A.)
}

\begin{abstract}
Snow fences built up-wind of natural snowdrifts at four alpine sites in the Colorado Rocky Mountains changed snow accumulation appreciably. The $3 \mathrm{~m}$ tall fences increased the amount of snow at three sites but decreased it at the fourth. At two of the three sites where snow was increased, there was no change in melt rate, so the additional snow prolonged the melt period $\mathrm{I}-3$ weeks. Fences most successfully augmented natural snow accumulation at sites with level or gently sloping terrain down-wind from the

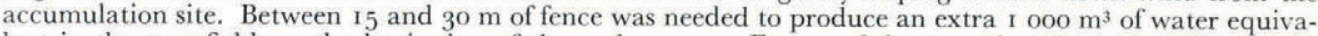
lent in the snowfields at the beginning of the melt season. Fences of the type described here, if properly located, are a means of increasing summer stream flow from alpine areas.

RÉsumé. Experimentation de barrières à neige en zone alpine. Des barrières à neige construites à l'amont de congères naturelles dans quatre sites de montagne dans les Colorado Rocky Mountains ont modifié de manière appréciable l'accumulation de la neige. Des barrières hautes de $3 \mathrm{~m}$ ont accru l'enneigement en trois sites mais l'on diminué au quatrième. Sur deux des trois sites où l'enneigement avait augmenté, il n'y avait pas de changement dans la vitesse de fusion. Les barrières se montrèrent les plus efficaces pour augmenter l'accumulation naturelle de la neige dans les endroits où il y avait un terrain horizontal ou à faible pente sous le vent du lieu d'accumulation. Il fallait entre 20 et $30 \mathrm{~m}$ de barrières pour produire un supplément de $\mathrm{I}$ ooo $\mathrm{m}^{3}$ d'équivalent en eau dans le manteau neigeux en début de saison de fusion. Les barrières du type décrit ici, si elles sont convenablement placées, sont un moyen d'accroître les écoulements hydrologiques à partir des zones de montagne.

Zusammenfassung. Versuche mit Schneezäunen im Gebirge. Schneezäune, die im Luv der natürlichen Schneedrift an vier alpinen Stellen in den Rocky Mountains von Colorado errichtet wurden, veränderten die Schneeablagerung beträchtlich. Die $3 \mathrm{~m}$ hohen Zäune erhöhten die Schneemenge an drei Stellen, aber verringerten sie an der vierten. An zwei der drei Stellen mit erhöhter Schneemenge änderte sich die Schmelzgeschwindigkeit nicht, so dass der zusätzliche Schnee die Schmelzperiode um $\mathrm{I}-3$ Wochen verlängerte. Zäune erhöhten die natürliche Schneeablagerung am wirkungsvollsten leeseits von Stellen im ebenen oder leicht abfallenden Gelände. Für eine Zunahme von $1000 \mathrm{~m}^{3}$ Wasserwert in den Schneefeldern am Beginn der Schmelzperiode waren Zäune zwischen $15 \mathrm{~m}$ und $30 \mathrm{~m}$ Länge notwendig. Zäune der hier beschriebenen Art sind, wenn sie richtig gesetzt werden, ein Mittel zur Erhöhung des sommerlichen Abflusses aus Gebirgsgebieten.
\end{abstract}

LAND managers have long been interested in improving water yields from mountainous areas, especially in the semi-arid parts of middle latitudes. For the high-elevation, wind-swept alpine areas where vegetation manipulation is not practical, snow fences or other artificial wind barriers have been suggested to improve late summer stream flow (Martinelli, 1959, 1966). Fences properly located along the windward edge of deep natural snowfields create additional snow deposition and thus increase the amount of snow available for summer stream flow. 5 years' experience with such fences at several sites in the lee of a major ridge and at one site on a windy ridge crest in the Front Range of central Colorado have been reported (Martinelli, I965). The lee sites showed mixed results, with fences giving good additional accumulation at some places, but reducing natural accumulation at others. Best results were obtained at Straight Creek Pass-the ridge-crest site.

This paper discusses how snow fences changed snow accumulation at Straight Creek Pass and three other windy alpine sites selected to give a range of topographical conditions.

\section{STUdy SITES}

Deep natural snowfields at windy sites between elevations of 3700 and $3800 \mathrm{~m}$ ( 12 ooo and $12500 \mathrm{ft}$ ) in the Front Range of central Colorado were selected for study. At Straight Creek Pass (Fig. I) the snowfield is in a long trough immediately to the lee of a north-south

\footnotetext{
* Central headquarters maintained in cooperation with Colorado State University, Fort Collins, Colorado 8052 I, U.S.A.
} 
ridge crest. The windward (west) approach is a smooth grassy up-slope with a gradient of about $\mathrm{I}_{5}{ }^{\circ}$ for a distance of $\mathrm{I}_{20-} \mathrm{O} 50 \mathrm{~m}(400-500 \mathrm{ft})$. The down-wind area is also grass-covered and slopes gently upward from the eastern edge of the snowfield. A major stream flows to the south-west. There is an east-west ridge about $1.2 \mathrm{~km}(0.75 \mathrm{mile})$ north of the site. Only one isolated knob on this ridge exceeds the elevation of the study site. Winds during snowfall and snowdrifting are mostly westerly. Snow normally lasts until mid-August.
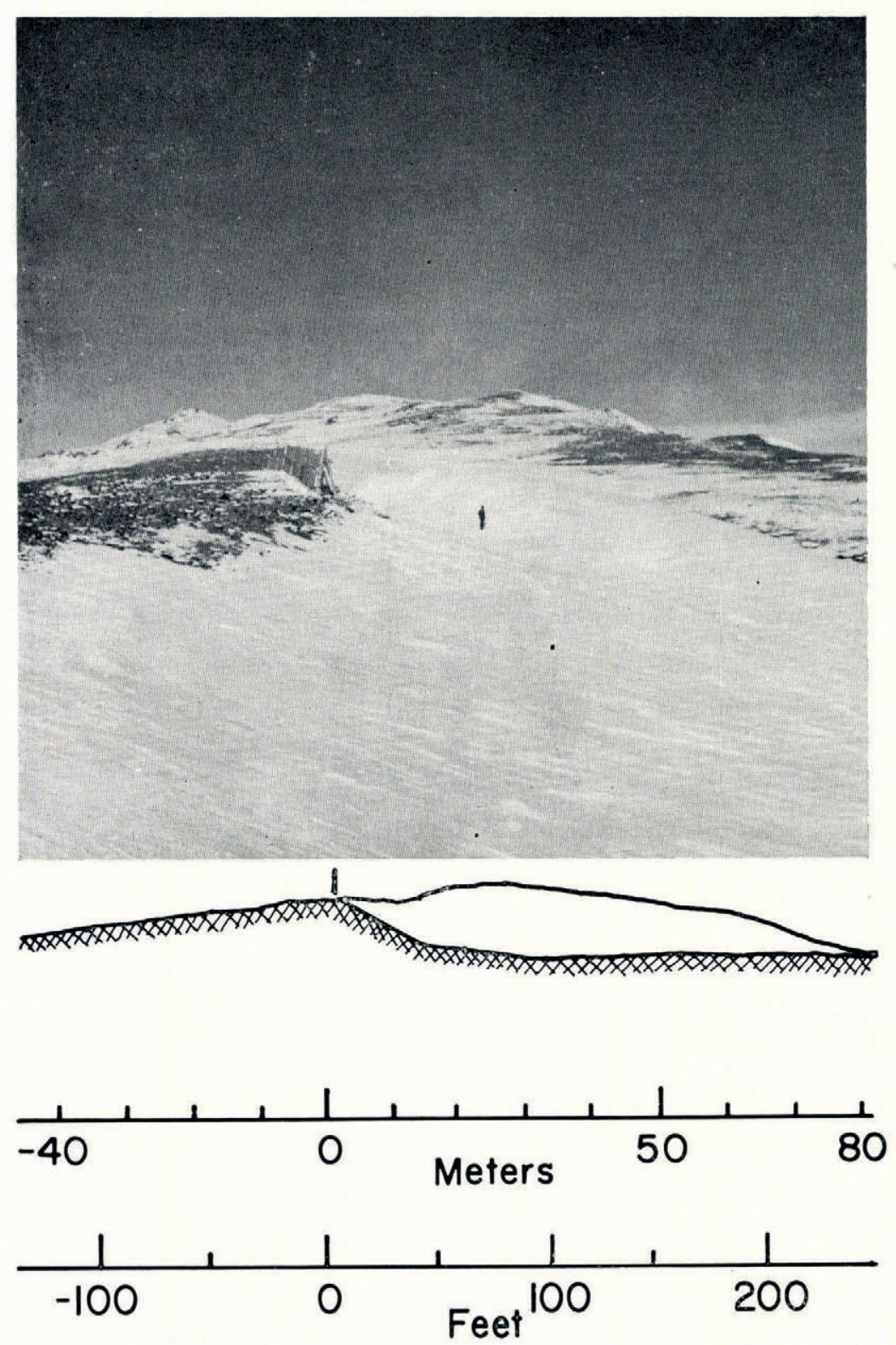

Fig 1 . Straight Creek Pass snowfield, 3 February 1963. Natural snow accumulation in foreground of picture. Person is standing in a depression caused by wind blowing under the fence. The profile is a generalization of maximum snow accumulation behind the fence. (Vertical and horizontal scales are equal.) Wind flows from left to right. 
The Mount Evans snowfield (Fig. 2) occupies the nearly flat floor of a solifluction terrace in the middle of a broad grass-covered valley that slopes gently $\left(8-\mathrm{IO}^{\circ}\right)$ downward to the east for almost $3.2 \mathrm{~km}$ (2 miles). Mountains to the north, west and south form a crescent of higher terrain. The peaks to the north and west are $150-300 \mathrm{~m}(500-1000 \mathrm{ft})$ higher than the study site; those to the south-west are $600 \mathrm{~m} \mathrm{(2} \mathrm{ooo} \mathrm{ft)} \mathrm{higher.} \mathrm{Winds} \mathrm{funnel} \mathrm{through} \mathrm{the} \mathrm{gaps}$
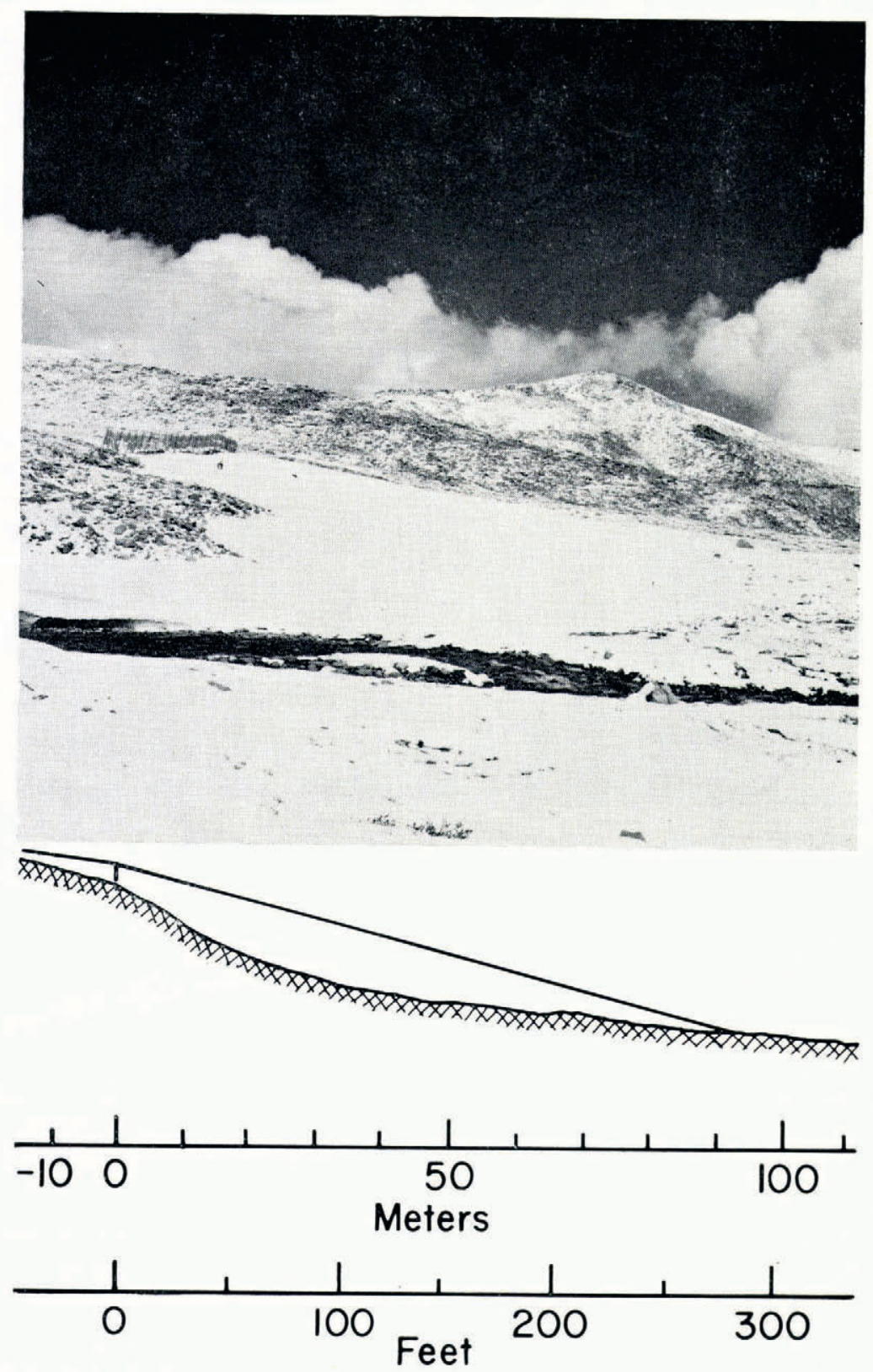

Fig. 2. Mount Evans snowfield, I August $196_{5}, I$ d after a $15 \mathrm{~cm}$ ( 6 inches) snowfall. Two people on the snow give scale. The profile is a generalization of maximum snow accumulation behind the fence. (Vertical and horizontal scales are equal.) Wind flows from left to right. 

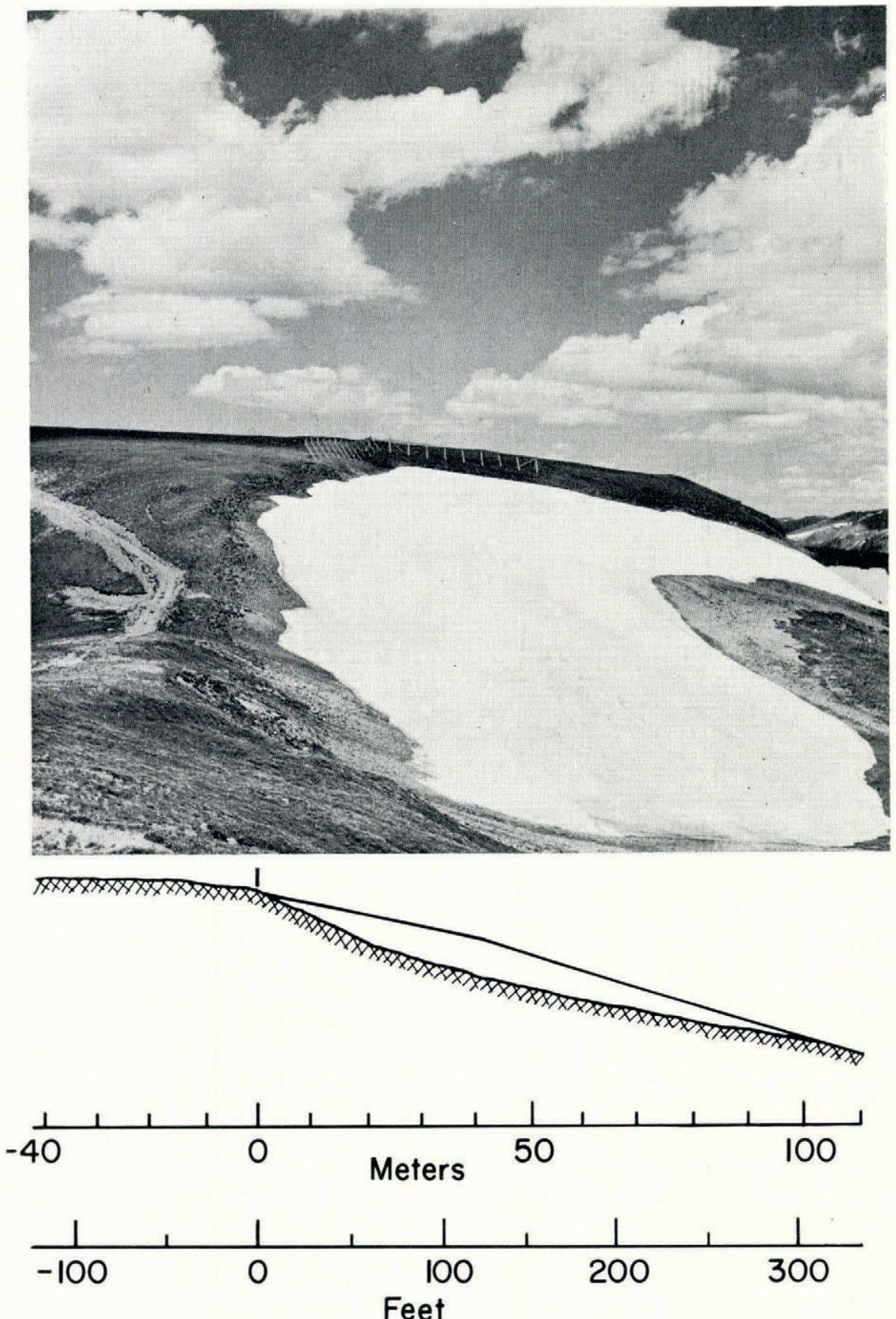

Fig. 3. Teller Mountain snowfield, I4 July 1966. Dirty snow in lower right edge of photograph is left over from summer of 1965 . The profile is a generalization of maximum snow accumulation behind the fence. (Vertical and horizontal scales are equal.) Wind flows from left to right. 

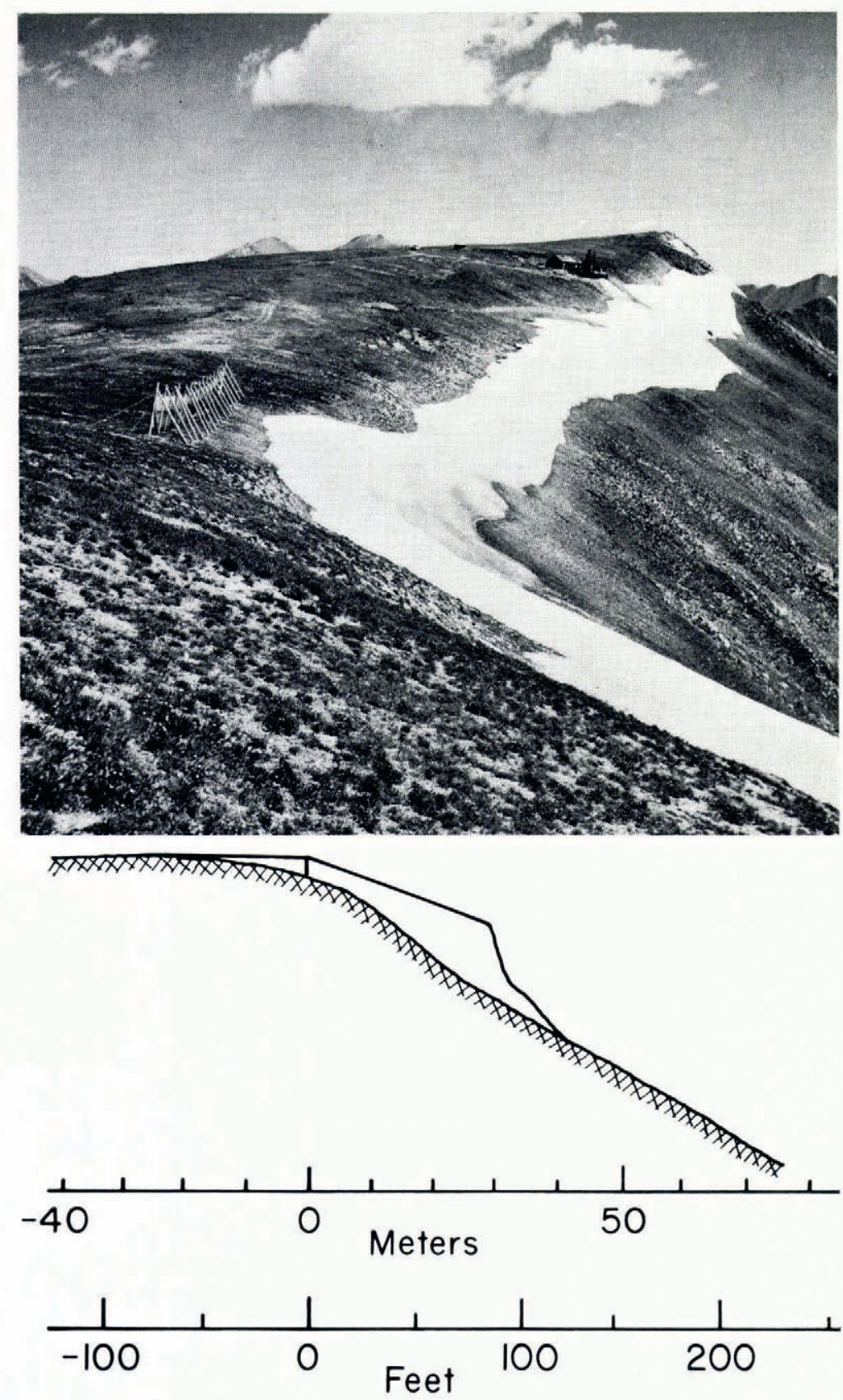

Fig. 4. Glacier Mountain snowfield, 6 August 1965 . The tendency for the natural snowfield to be drawn up-hill behind the fence is noticeable in this photograph. The profile is a generalization of maximum snow accumulation behind the fence. (Vertical and horizontal scales are equal.) Wind flows from left to right. 
between the peaks but they are mostly westerly down the valley. The long axis of the field is roughly north-south. Snowfall at this site is thought to be about half that at the other sites because of its location east of the Continental Divide. Snow normally persists in the deeper parts of the snowfield until early September.

At the Teller Mountain snowfield (Fig. 3), snow accumulates on a bench in the lee of a north-west-south-east break in the terrain. Beyond the bench the lee slope drops steeply to the valley below. Early in the season the snowfield extends all the way across the northern end of the bench, but only about two-thirds of the way across the southern end. The windward approach to this site is complex. North-west winds blow across a flat, grass-covered area $1.2 \mathrm{~km}$ (0.75 mile) long. South-west winds flow up a valley that is $0.5 \mathrm{~km}$ (0.3 mile) wide. It is not certain how westerly winds are channeled by the terrain. Snow usually persists all summer at this site.

Glacier Mountain snowfield (Fig. 4) forms along the moderately steep $\left(25^{\circ}\right)$ south-east side of this north-east-south-west orientated mountain. The snow accumulates on the side of

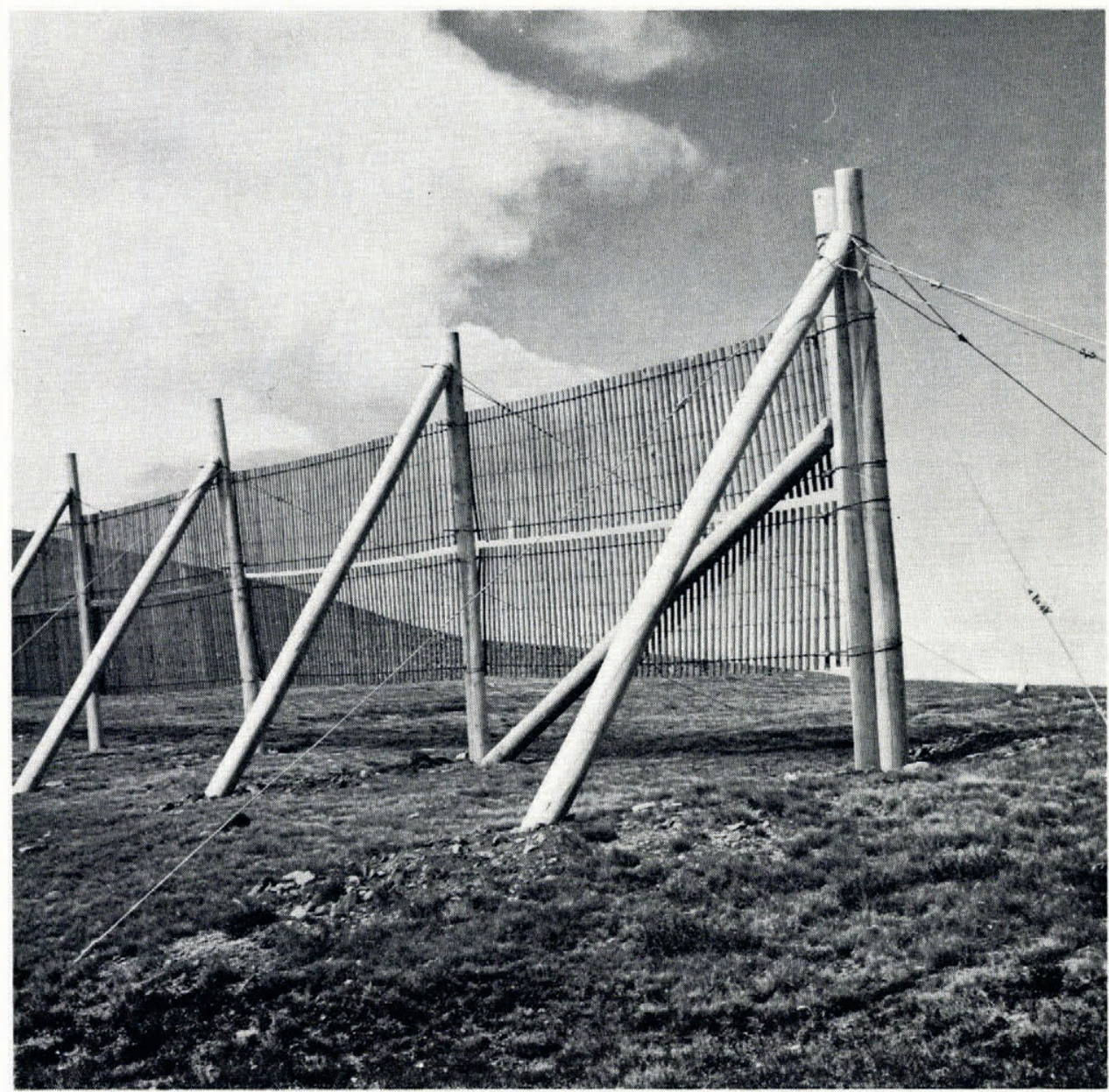

Fig. 5. Snow fence of the type used in this study. Doubled end poles and stout back braces were needed at these windy sites. The guy wires are satisfactory if no snow accumulates on them. If they become buried, snow settlement exerts tremendous pressure on the fence. 
the mountain and not in a depression as it does at all the other sites. The study site is east of a gap or shallow saddle in the main ridge, which increases gently in elevation north-east and south-west of the study site. The mountain is rounded in cross-section, grass-covered and relatively smooth. North-westerly winds flow directly through the gap toward the study site. Down-wind of the snowfield the slope drops at a gradient of $25^{\circ}$ for about $150 \mathrm{~m}(500 \mathrm{ft})$ then flattens out into a bench. Snow normally is gone from this field by the end of August.

\section{Methods}

At each study site, a snow fence 60-100 m (180-330 ft) long was built along the windward edge of the natural snowfield. Fences were built by attaching two $1.2 \mathrm{~m}(4 \mathrm{ft})$ tiers of a commercially available mat made of narrow wood slats and wire to a stout framework of wooden poles and steel cables. The barriers had a density of $42 \%(58 \%$ open $)$ and were $3-3.7 \mathrm{~m}$ ( $10-12 \mathrm{ft}$ ) tall including the gap between the fencing and the ground. The face of the barrier was tilted down-wind about $6-7^{\circ}$ from the perpendicular to increase the efficiency of the back braces (Fig. 5).

During spring and summer, vertical angle and slope distance were measured at 7-I4 $\mathrm{d}$ intervals along four parallel lines across the snowfield. Two of these profile lines, called test lines, were behind the fence and two, called control lines, were beyond the influence of the fence.

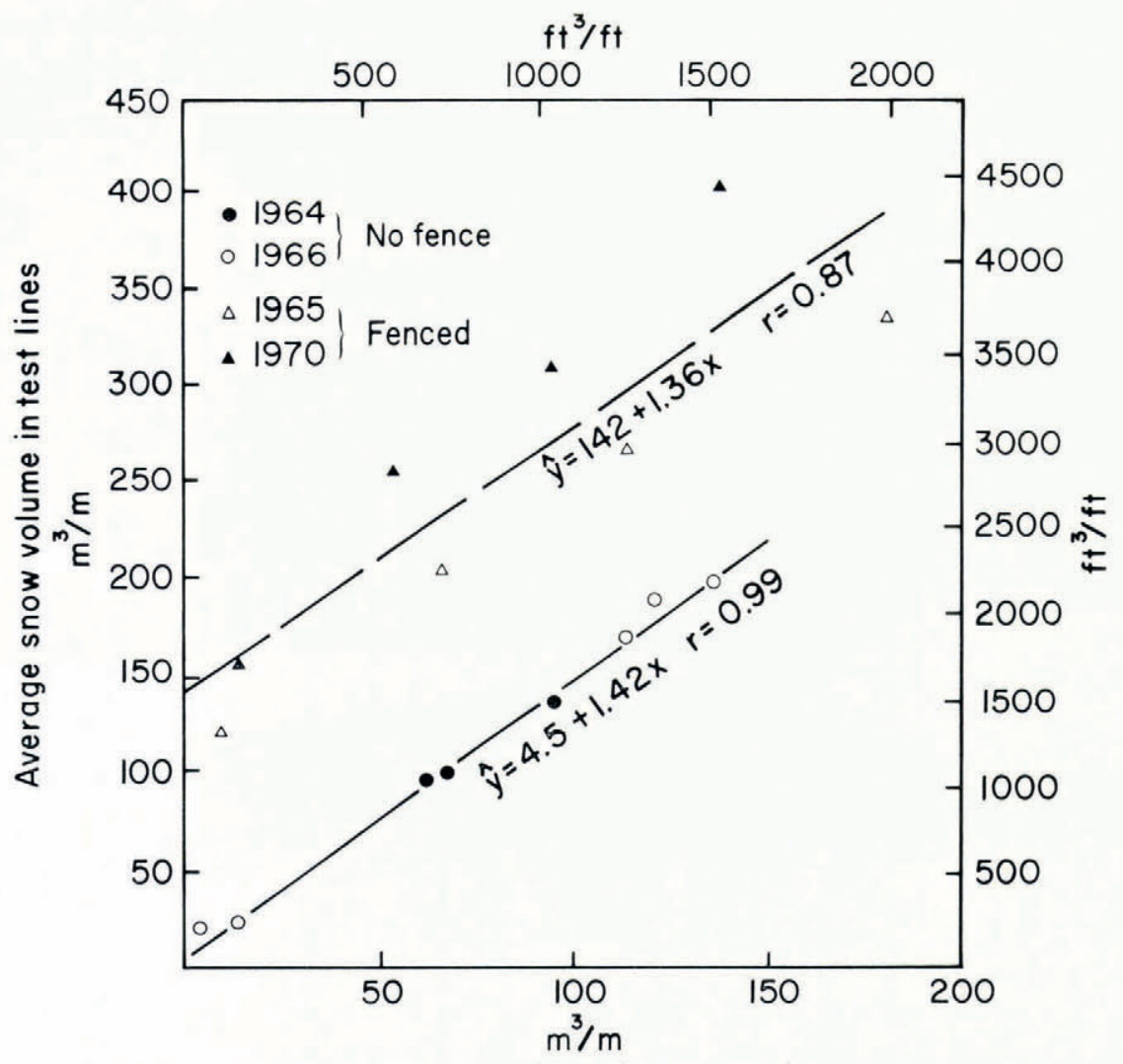

Average snow volume in control lines

Fig. 6. Snow volume, average snow depth and length of snow-profile lines behind the fence (test lines) as a function of natural conditions (control lines) at Straight Creek Pass. 
Cross-section areas of the snowdrifts were determined by planimetering scale drawings of the ground and snow profiles for estimates of snow volumes. Horizontal lengths of the snow profiles were measured directly from the drawings. Average snow depths were calculated by dividing cross-section areas by horizontal lengths.

Graphs and regressions were developed for snow volume, average snow depth, and length of profile lines for the test lines as a function of the control lines under natural and fenced conditions at each field. Differences in the amount of snow in the test lines for years with fences compared to years without fences were considered to be fence effects. This is justified because the fields tend to fill uniformly and because there was enough snow most years to saturate the control area. The analysis worked well for all but Teller Mountain, where a slight modification, described later, was used.

\section{Results}

Best results were obtained at Straight Creek Pass. Here the fence increased total snow volume at the start of the melt season by $\mathrm{I}_{35} \mathrm{~m}^{3}$ of snow per lineal meter of fence $\left(\mathrm{I} 55^{\mathrm{Oo} \mathrm{ft}} \mathrm{ft}^{3} \mathrm{ft}\right)$ or about $75^{-80} \%$ and average snow depth by $2 \mathrm{~m}(6.5 \mathrm{ft})$ (Fig. 6). Ablation rates were not affected so snow persisted about 3 weeks longer with the fence than without it (Fig. 7). Little effect could be noticed on length of the snow-profile lines until late July or early August, when the fenced lines remained $\mathrm{I} 2-18 \mathrm{~m}(40-60 \mathrm{ft})$ longer than the unfenced due to slower recession of the deep drift behind the fence. The upward slope of the terrain beyond the eastern edge of the normal snowfield tended to shorten fence effect and prevent a significant increase in length of line behind the fence.

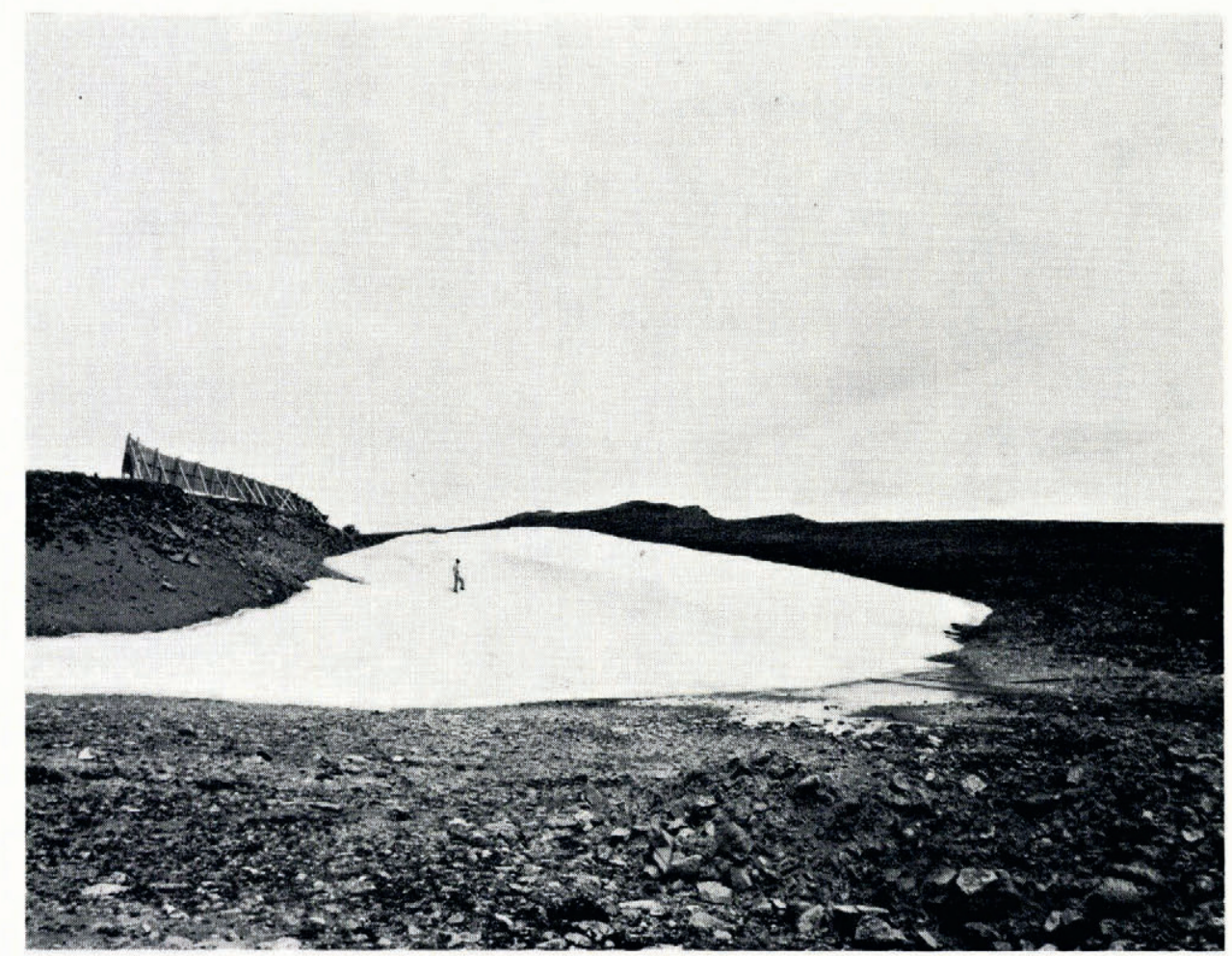

Fig. 7. Best fence results were obtained at Straight Creek Pass. On 9 August 1962, the additional $1.8-2.1 \mathrm{~m}(6-7 \mathrm{ft})$ of snow accumulated behind the fence is still obvious. 
The smooth up-slope approach, together with the ridge-crest location of the fence and the

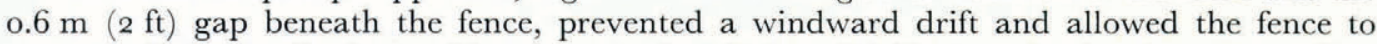
operate efficiently all winter. The absence of a windward drift not only gives best fence effect but it also eliminates the damage to a buried fence caused by snow settlement.

At maximum snow depth, a distance of $3 \cdot 5^{-4.5} \mathrm{~m}\left(\mathrm{I}_{2}-\mathrm{I} 5 \mathrm{ft}\right)$ behind the fence was blown clear of snow by air jetting under the fence. The snow then deepened rapidly into a distinct mound that had a steep lee face early in the winter, but usually filled to a gently rounded surface by spring. This was in sharp contrast to the normal streamlined filling of the terrain depression at this site (foreground of Figure $\mathrm{I}$ ).

At Mount Evans, the fence increased volume of snow $55^{-} 73 \mathrm{~m}^{3} / \mathrm{m}$ of fence $\left(600-800 \mathrm{ft}^{3} / \mathrm{ft}^{2}\right)$ (Fig. 8), average snow depth $0.6-0.8 \mathrm{~m}(2-2.5 \mathrm{ft})$, and length of profile lines $12-15 \mathrm{~m}(40-50$ $\mathrm{ft}$ ). The down-slope approach resulted in a windward drift that engulfed the fence in spite of a I.2-I.4 $\mathrm{m}(4-4.5 \mathrm{ft})$ gap beneath the fence.

At maximum snow depth, most of the $3.7 \mathrm{~m}$ ( $12 \mathrm{ft}$ ) fence was buried and the entire area had a smooth rounded appearance. Damage to the fence from snow settlement was extensive each year. The gentle down-slope gradient east of the snowfield combined with the normal fence effect to give an increased volume that resulted from added length as well as depth.

At Teller Mountain, wind direction during snowdrifting proved to be different than expected. Field observations in the early summer of 1965 indicated that the drift from the fence fell more on the control lines adjacent to the fence than on the test lines behind the fence.

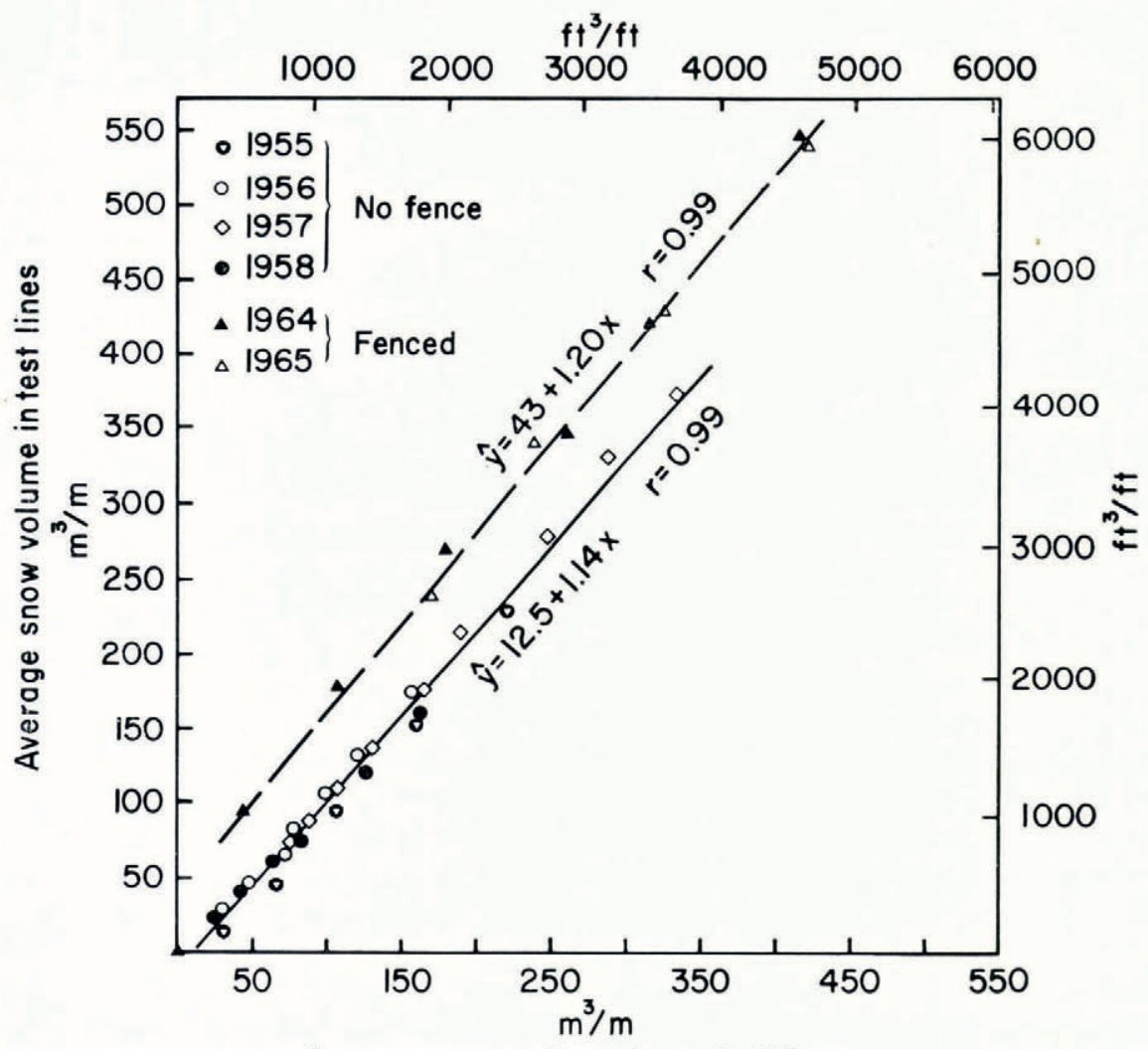

Average snow volume in control lines

Fig. 8. Snow volume, average snow depth and length of snow-profile lines behind the fence as a function of natural conditions at Mount Evans. 
Additional fence was built along the northern side of the field in an attempt to confine fence effect to the test lines. Erratic results indicated the additional fence did not completely correct the problem. It was therefore decided to use the control lines on Glacier Mountain to measure fence effect on all four profile lines at Teller Mountain. The Glacier Mountain control lines appeared to be free of fence effect, and the two sites were only $4.8 \mathrm{~km}$ ( 3 miles) apart and in similar terrain.

The long fence ( 1966 and I967) at Teller Mountain increased early summer snow volumes and average snow depths $150 \mathrm{~m}^{3} / \mathrm{m}$ of fence $\left(\mathrm{I} 65^{0} \mathrm{ft}^{3} / \mathrm{ft}\right)$ and $1.7 \mathrm{~m}(6 \mathrm{ft})$, respectively (Fig. 9). This early season increase did not persist through the melt season, however, so that by late summer there was less snow with the fence up than under natural conditions. Why the depletion rate increased so sharply with the long fence is not known. It could be the short period of record or poor control.

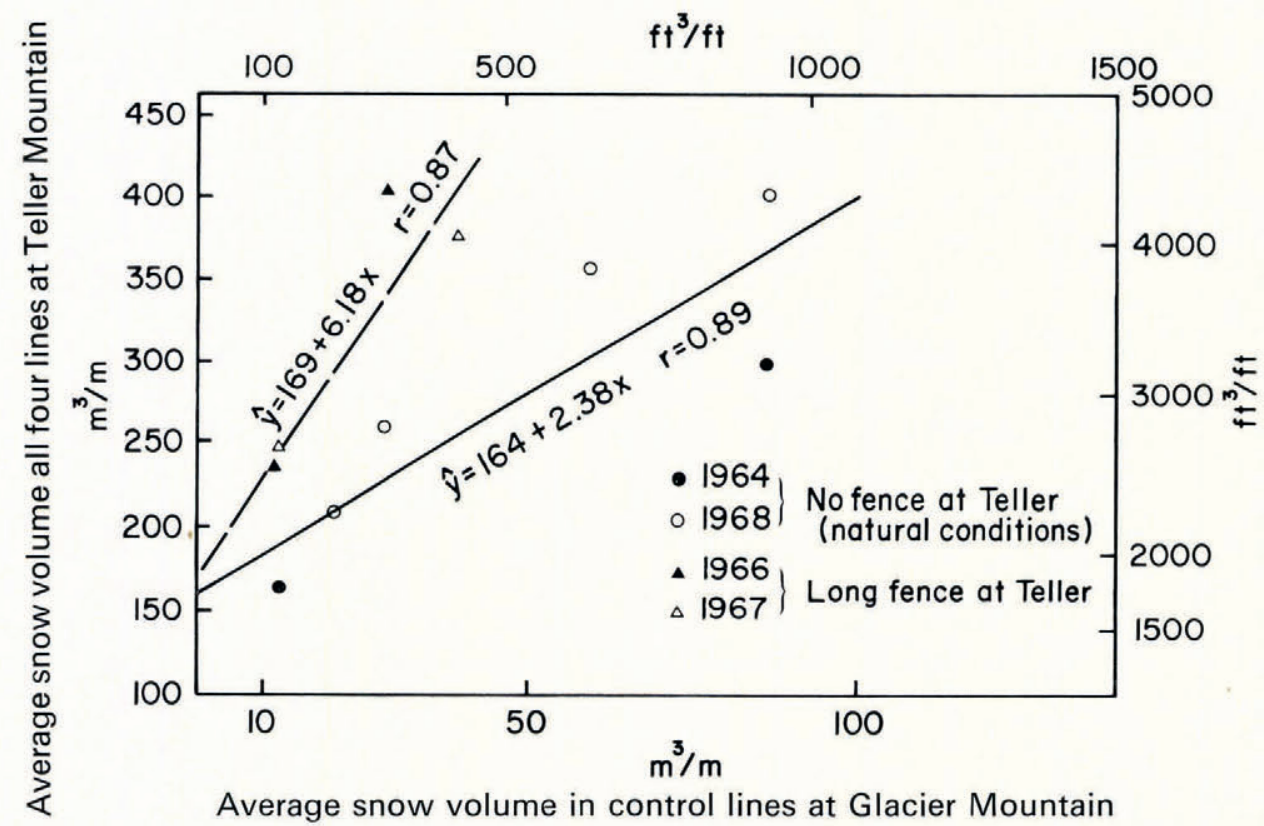

Fig. 9. Snow volume, average snow depth and length of snow-profile lines in all four lines at Teller Mountain as functions of natural conditions at Glacier Mountain.

The fence at Glacier Mountain reduced the volume of snow $56 \mathrm{~m}^{3} / \mathrm{m}$ of fence $\left(600 \mathrm{ft}^{3} / \mathrm{ft}\right)$

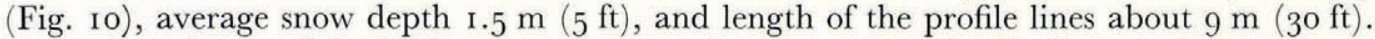
In the fenced part of the field, snow volume and average snow depths decreased more slowly and average length of profile more rapidly than under natural conditions (Fig. Io), possibly because the drift behind the fence was a little more in the shade of the ridge than before. These reduced rates, however, did not compensate for the large initial volume deficit, $85 \mathrm{~m}^{3} / \mathrm{m}^{2}$ $\left(\mathrm{I} 000 \mathrm{ft}^{3} / \mathrm{ft}\right)$, so that at the end of the summer there was still almost $27 \mathrm{~m}^{3} / \mathrm{m}\left(300 \mathrm{ft}^{3} / \mathrm{ft}\right)$ less snow behind the fence than under natural conditions.

The fence location at Glacier Mountain was something less than ideal for our purpose. The natural snowfield was about $35-40 \mathrm{~m}$ ( $\mathrm{I}_{\mathrm{IO}-\mathrm{I}} 3_{\mathrm{O}} \mathrm{ft}$ ) leeward of the ridge crest. The best fence site for keeping the fence free of a windward drift and maintaining high trapping efficiency all winter would have been the ridge crest. A fence here, however, would have thrown a drift well up-slope of the natural snowfield. 
The location chosen was $5^{-8} \mathrm{~m}\left(\mathrm{I}^{-25} \mathrm{ft}\right)$ up-slope of the western edge of the snowfield

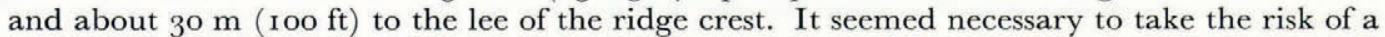
windward drift burying the fence in order to get the fence effect to fall on the natural snowfield, as required by our primary objective of creating drifts deep enough to contribute to late summer stream flow. The first winter $(1964-65)$ a windward drift did partially bury the fence, so the density of the lower tier of fencing was reduced to $20 \%$. This helped a little but the lee drift still formed close to the fence and net snow accumulation was reduced from natural conditions.

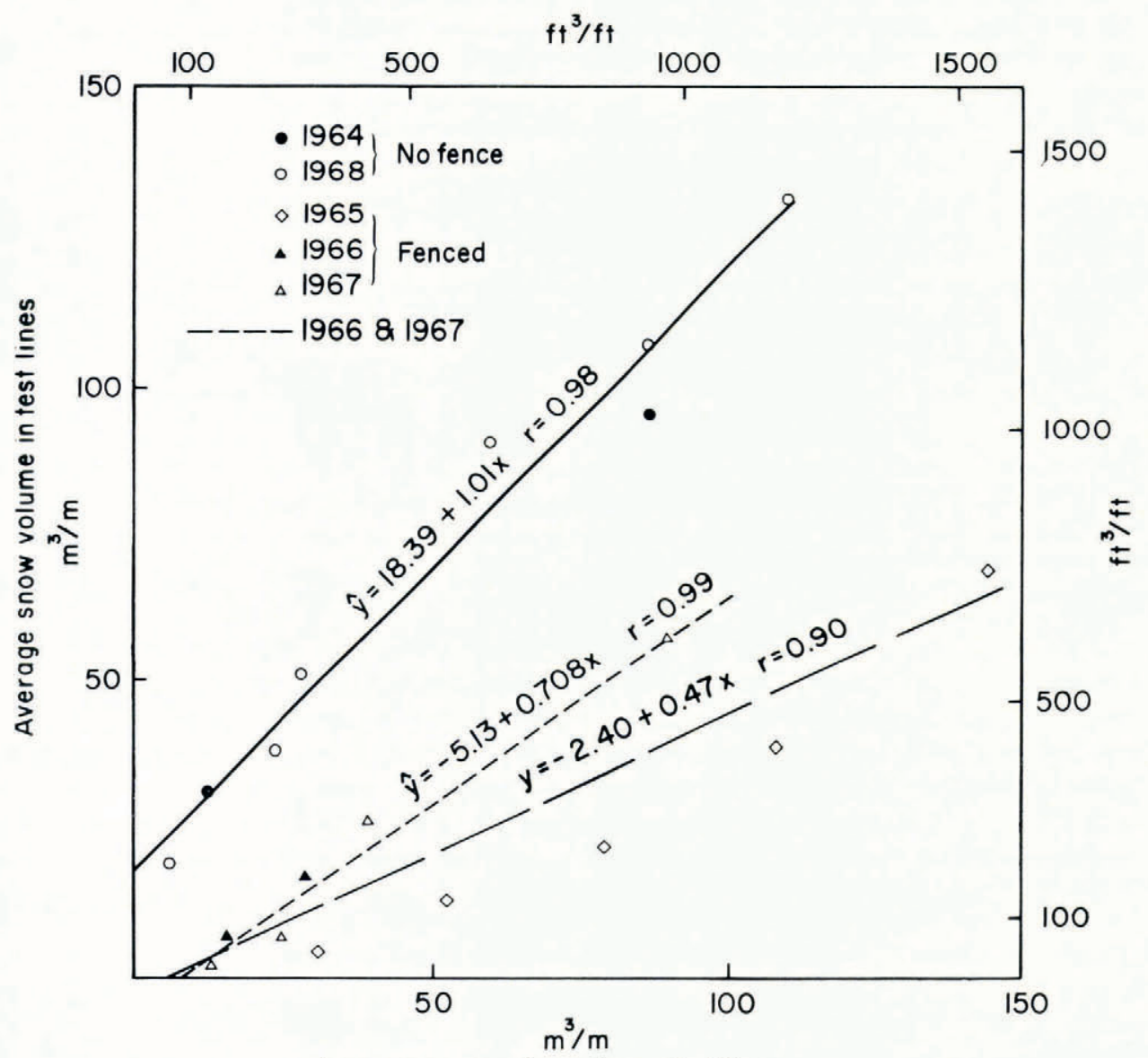

Average snow volume in control lines

Fig. Io. Snow volume, average snow depth and length of the profile lines behind the fence as a function of natural conditions at Glacier Mountain.

\section{Conclusions}

At three of four alpine sites in the central Rocky Mountains, large snow fences appreciably increased snow accumulation on natural snowfields. At two of these sites, the increased accumulation persisted all summer and prolonged the melt season I-3 weeks. Extra accumulation at the third successful site was accompanied by a more rapid melt rate so that early summer run-off was increased, but the melt season was not prolonged. The fence at the fourth site decreased the amount of snow normally present in the natural snowfield. 
All successful fences were windward of snowfields that had level or gently sloping terrain beyond their down-wind edges. The unsuccessful fence was part-way down a lee slope that became steep just below the fence and remained steep for some distance beyond the snowfield. Schmidt (1970), in his discussion of wind-flow data taken at these sites, pointed out that fences above steep slopes encourage a reverse wind flow that can become strong enough to erode the natural snowdrift. This, together with the blocking of the gap below the fence by the windward snowdrift, is probably what happened at Glacier Mountain.

Net fence effect at Mount Evans was only half that at Straight Creek Pass. It is interesting to speculate what could be achieved at the Mount Evans site, if a barrier could be devised that would not become buried and would therefore remain effective all winter.

It is significant that, at both Straight Creek Pass and Mount Evans, the rate of depletion of snow volume and average snow depth was the same for fenced and natural conditions. This means the snow added by the fence will prolong the melt season and not just increase early summer run-off.

TAble I. Regressions, EQUATIONS AND correlation coefFicients $(r$ ) FOR SNOW volume IN TEST LINES $(\hat{Y})$ AS A FUNCTION OF SNOW VOLUME IN CONTROL LINES $(x)$

\begin{tabular}{|c|c|c|c|c|c|}
\hline Snowfield & \multicolumn{5}{|c|}{ Conditions at the field } \\
\hline Straight Creek Pass & $\hat{r}=4.5+1.42 x$ & $r=0.99$ & $\hat{\Upsilon}=$ & $142+1 \cdot 36 x$ & $r=0.87$ \\
\hline Mount Evans & $\hat{r}=12.5+1.14 x$ & $r=0.99$ & $\hat{r}=$ & $43+1.20 x$ & $r=0.99$ \\
\hline Teller Mountain* (long fence) & $\hat{\gamma}=164+2.3^{8} x$ & $r=0.89$ & $\hat{r}=$ & $169+6.18 x$ & $r=0.87$ \\
\hline Glacier Mountain & $\hat{\Upsilon}=18.4+1.01 x$ & $r=0.98$ & $\hat{Y}=$ & $-5.1+0.71 x$ & $r=0.99$ \\
\hline
\end{tabular}

* Snow volume in the four lines at Teller Mountain was estimated from the volume in the two control lines at Glacier Mountain because the Teller Mountain control lines were not free of the fence effect.

Increases in snow volume (Table I) were greatest where the fence remained free of snow all winter. This was achieved at sites with a level or up-slope approach to the fence. Reducing the density of the lower half of one fence where a windward drift partly buried the fence helped but did not solve the problem. Damage to fences buried in their own drift was so extensive that another type of barrier should be considered for such places. At a good drift site like Mount Evans, it is possible that a rock or earth wall would induce a drift much like the one caused by the buried fence, and the more massive structure would not be damaged by snow settlement.

Based on an average snow density of $500 \mathrm{~kg} \mathrm{~m}^{-3}$ in these fields, the following amounts of snow fence were needed to produce an extra $\mathrm{I} 000 \mathrm{~m}^{3}$ of water at the beginning of the melt season:

$\begin{array}{lll}\text { Straight Creek Pass } & \text { I } 5 \mathrm{~m} & \text { (6o ft of fence/acre- } \mathrm{ft} \text { of water) } \\ \text { Mount Evans } & \text { 3 } \mathrm{I} \mathrm{m} & \text { (I } 25 \mathrm{ft} \text { of fence/acre- } \mathrm{ft} \text { of water) } \\ \text { Teller Mountain } & 27 \mathrm{~m} & \text { (I I } \mathrm{ft} \text { of fence/acre-ft of water) }\end{array}$

These amounts compare favorably with the $50 \mathrm{~m}$ of the same type of fence needed per $\mathrm{I} 000 \mathrm{~m}^{3}$ of water (200 ft of fence/acre-ft of water) for lower-elevation grasslands of eastern Wyoming (Tabler, I970).

Land managers planning to use fences to modify the natural snowpack should select the sites with care. Fences should remain free of their own drifts to assure winter-long efficiency and to avoid the structural damage caused by settling snow. Sites should be chosen so the modification caused by the fence will contribute to the primary management goal, whether this be increasing spring run-off, decreasing snow depths in avalanche-prone areas, or supplementing late summer stream flow. Snow fences located with care and discretion can be 
a useful resource management tool, but the indiscriminate construction of fences along entire ridge crests or up-wind of a random assortment of natural snowfields will seldom achieve the desired results.

MS. received I 8 October 197 I and in revised form I fanuary 1973

\section{REFERENCES}

Martinelli, M., jr. I959. Alpine snowfields-their characteristics and management possibilities. Union Géodésique et Géophysique Internationale. A sociation Internationale d'Hydrologie Sientifique, Colloque de Hannoveisch Münden. 8-14 Sept. 1959, Tom. I, P. I 20-127.

Martinelli, M., jr. 1965 . Accumulation of snow in alpine areas of central Colorado and means of influencing it. Journal of Glaciology, Vol. 5, No. 41, p. 625-36.

Martinelli, M., jr. I966. Possibilities of snowpack management in alpine areas. (In Sopper, W. E., and Lull, H. W., ed. Forest hydrology: proceedings of a National Science Foundation advanced science seminar held at the Pennsylvania State University..., Aug. 29-Sept. IO, I965. Oxford and New York, Pergamon Press, p. 225-31.)

Schmidt, R. A., jr. 1970. Locating snow fences in mountainous terrain. (In Snow removal and ice control research. Proceedings of an international symposium held April 8-10, 1970. [U.S.] Highway Research Board. Special Report I $_{15}$, p. 220-25.)

Tabler, Ronald D. 1971. Design of a watershed snow fence system, and first-year snow accumulation. Proceedings of the Western Snow Conference, 39th annual meeting, I971, p. 50-55. 